\title{
Isolation and Characterization of Buffalo Wharton's Jelly Derived Mesenchymal Stem Cells
}

\author{
Sreekumar TR*, Mohd Matin Ansari, Vikash Chandra and G Taru Sharma
}

Reproductive Physiology Laboratory, Division of Physiology and Climatology, Indian Veterinary Research Institute, Izatnagar -243 122 (UP), India

\begin{abstract}
Bone marrow and adipose tissue are the most common sources of animal mesenchymal stem cells. However Wharton's jelly derived stem cells which could be collected non-invasively can be an alternative and good source of stem cells. The objective of present study was to isolate and characterize putative stem cell population from Wharton's jelly derived cells. Fibroblastoid, plastic adherent cells could be successfully isolated from Wharton's jelly and expanded in vitro conditions. Cells showed high proliferation ability and stained positively for alkaline phosphatase. Expression profile of surface cell markers and pluripotency markers were analyzed using immunocytochemistry and RT-PCR. Relative transcript abundance of pluripotency markers were analyzed by SYBR green based real time PCR. Karyotyping was done to demonstrate chromosome integrity. When corresponding induction conditions were applied, bWJ-MSCs differentiated into osteogenic, adipogenic and chondrogenic lineages which was confirmed through von Kossa, Oil Red O and Alcian blue staining respectively. In conclusion, buffalo Wharton's jelly represents a promising source of mesenchymal stem cells with high proliferative and differentiation potential and these cells could provide great scope for multiple regenerative therapies.
\end{abstract}

Keywords: Buffalo Wharton's jelly; Umbilical cord; Jelly explants; Immunocytochemistry; Differentiation

\section{Introduction}

Fetal and adult stem cells have the potential to play vital role in livestock production and management. Fetal stem cells in comparison to stem cells from other sources are easily accessible and can be isolated in larger quantities. Additionally it can provide new insights into development biology of animals. Fetal stem cells may develop as a valuable source of stem cells for clinical applications in large animals. According to ISCT (International Society for Cellular Therapy) mesenchymal stem cells can be defined by three criteria 1) Mesenchymal stem cells must be plastic-adherent when maintained in vitro; (2) Mesenchymal stem cells must express CD73, CD90 and CD105, and lack expression of CD34, CD45, CD14 or CD11b, CD79a or CD19 and MHC class II antigens; (3) The MS cells must differentiate into osteoblasts, adipocytes and chondroblasts in vitro [1].

MSCs are most commonly sourced from bone marrow. As bone marrow harvesting is a highly invasive procedure, alternative sources for MSC isolation have been pursued. Recent studies reported MSCs can be sourced from several regions of umbilical cord including Wharton's jelly [2]. Wharton $>$ jelly is the gelatinous connective tissue from umbilical cord and is composed of myofibroblast-like stromal cells, collagen fibers, and proteoglycans [3]. Wharton's jelly cells were successfully isolated from human and porcine umbilical cord tissue and explanted as primary culture [2,4]. Studies have reported that they possess the multilineage differentiation potential $[5,6]$. They have been isolated from different species like humans, dog, pig, horse, sheep, bovine and goat. The objective of the present study was to isolate, culture and characterize buffalo Wharton's jelly derived mesenchymal stem cells (bWJ-MSCs)

\section{Materials and Methods}

All the chemicals used in this study were procured from Sigma (St. Louis, MO, USA), unless otherwise indicated. The primary and secondary antibodies used for immunocytochemistry were purchased from Santa Cruz Biotechnology, USA.

\section{Isolation and culture of Buffalo Wharton's jelly derived stem} cells

Gravid buffalo uteri $(\mathrm{n}=4)$ at later gestation period $\sim 3 \mathrm{M}$ old were collected from local abattoir and transported within two hours to the Reproductive Physiology Laboratory of Physiology and Climatology Division, Indian Veterinary Research Institute, Izatnagar, India. The umbilical cords were processed for isolation of WJ-MSCs as previously described by Babaei et al. [7], with some modifications. Briefly, after rinsing in normal saline, the cords were aseptically stored at $4^{\circ} \mathrm{C}$ in sterile saline until processing. The umbilical cord vessels were removed manually from cord segments, and the exposed mesenchymal connective tissues were cut into very small pieces or explants, approx. $1-2 \mathrm{~mm}$, before placing them in a disposable $35 \mathrm{~mm}$ tissue culture dish. The explants were cultured in DMEM medium fortified with $15 \%$ fetal bovine serum, $200 \mathrm{IU} / \mathrm{ml}$ penicillin, and $200 \mu \mathrm{g} / \mathrm{mL}$ streptomycin and maintained at $37^{\circ} \mathrm{C}$ in a humidified atmosphere of $5 \% \mathrm{CO}_{2}$. Wharton's jelly fragments were observed to be attached within $72 \mathrm{~h}$ of plating, jelly explants were removed from culture dishes a week after plating and the expanded cells were cultured for at least 7 more days and the medium was refreshed at every third day. Two weeks later the attached cells were harvested by 5 minutes enzymatic digestion where, cells were detached by treating with accutase (Sigma) for passage. For all the experiments stem cells were taken from third passage.

*Corresponding author: Sreekumar TR, Reproductive Physiology Laboratory, Division of Physiology and Climatology, Indian Veterinary Research Institute, Izatnagar -243 122 (UP), India, Tel: +919037223834; E-mail: drsreekumar07@ gmail.com

Received March 24, 2014; Accepted May 14, 2014; Published May 16, 2014

Citation: Sreekumar TR, Ansari MM, Chandra V, G Sharma T (2014) Isolation and Characterization of Buffalo Wharton's Jelly Derived Mesenchymal Stem Cells. J Stem Cell Res Ther 4: 207. doi:10.4172/2157-7633.1000207

Copyright: (C) 2014 Sreekumar TR, et al. This is an open-access article distributed under the terms of the Creative Commons Attribution License, which permits unrestricted use, distribution, and reproduction in any medium, provided the original author and source are credited. 


\section{Alkaline phosphatase staining}

Third passage bWJ-MSCs cultured and which formed a monolayer were subjected to alkaline phosphatase staining. Briefly, cell monolayer was rinsed in DPBS, fixed in $4 \%$ paraformaldehyde and then overlaid with $25 \mathrm{mM}$ Tris $\mathrm{HCl}$ (Promega, USA), $150 \mathrm{mM} \mathrm{NaCl}$ containing 8 $\mathrm{mM} \mathrm{MgCl} 2$, Naphthol AS-MX Phosphate $(0.4 \mathrm{mg} / \mathrm{ml})$ and Fast Red TR salt ( $1 \mathrm{mg} / \mathrm{ml}$ ) (Millipore, USA) for $20-30 \mathrm{~min}$ at $37^{\circ} \mathrm{C}$, rinsed again with DPBS. Similarly treated buffalo fetal fibroblast monolayer acted as negative control. Stained cells were observed under inverted light microscope (Olympus-CKX-41, Japan) [8].

\section{Osteogenic differentiation}

Cells of third passage which formed confluent monolayer were used to induce osteogenic differentiation. Cells were cultured in DMEM medium supplemented with $50 \mathrm{mg} / \mathrm{ml}$ ascorbic 2-phosphate, $10 \mathrm{nM}$ dexamethasone and $10 \mathrm{mM}$ b-glycerophosphate for three weeks; von Kosaa staining was then used to observe matrix mineralization. For staining, the cultures were first fixed in $70 \%$ methanol for $10 \mathrm{~min}$ and then subjected to von Kossa staining as per standard protocol [9].

\section{Adipogenic differentiation}

For adipogenesis, DMEM medium containing $100 \mathrm{nM}$ dexamethasone and $50 \mathrm{mg} / \mathrm{ml}$ indomethacin were added to $60-80 \%$ confluent culture of passage- 3 stem cells. Three weeks later, cells were fixed with $4 \%$ formalin at room temperature, washed with $70 \%$ ethanol and stained by Oil Red O solution in 99\% isopropanol for $15 \mathrm{~min}$ [10].

\section{Chondrogenic differentiation}

Chondrogenic differentiation was induced in confluent monolayer cultures of bWJ-MSCs using a specific chondrogenesis differentiation kit (StemPro, Invitrogen). Differentiated cells were stained with Alcian blue 8GX (Sigma-Aldrich) after 16-20 days [11].

\section{Karyotyping}

After 72 hours of growth, cells of 3rd passage were incubated in $0.4 \mu \mathrm{g} / \mathrm{ml}$ colchicine for $2 \mathrm{hrs}$ at $370 \mathrm{C}$ in $5 \% \mathrm{CO}_{2}$ incubator. Cells were washed twice in PBS and harvested using accutase. The cells were later suspended in hypotonic solution $(75 \mathrm{mM} \mathrm{KCl})$ for 20 minutes at $37^{\circ} \mathrm{C}$. The cells were then fixed in chilled cornoys fixative (3:1 methanol/ glacial acetic acid) for 5 minutes at room temperature and centrifuged at $1400 \mathrm{rpm}$ for 5 minutes. Then pellet was washed twice with fresh chilled fixative and metaphase spread was prepared by dropping the cells on pre cleaned ice cold glass slides. Slides were stained in $4 \%$ Giemsa solution for 12 minutes and observed under compound microscope using oil immersion at 100X.

\section{Total RNA extraction and reverse transcription}

Total RNA was isolated from third passage bWJ-MSCs cells using Tri Reagent RT (Molecular Research Center Inc., USA) according to manufacturer's recommendations. The harvested cells were resuspended in $1 \mathrm{ml}$ Tri Reagent RT, pipetted well and supplemented with $50 \mu \mathrm{l}$ of bromoanisole followed by gentle shaking for $15 \mathrm{~s}$. The mix was centrifuged at $12000 \mathrm{rpm}$ for $15 \mathrm{~min}$ at $4^{\circ} \mathrm{C}$. The upper aqueous phase containing RNA was transferred to a new $1.5 \mathrm{ml}$ eppendorf tube and the RNA was precipitated by mixing $0.5 \mathrm{ml}$ of isopropanol. RNA was precipitated as a white pellet on centrifuging at $12000 \mathrm{rpm}$ for 5 $\min$ at $4^{\circ} \mathrm{C}$. The pellet was once again washed with $75 \%$ cold ethanol, air dried and dissolved in RNAse-free water and stored at $-80^{\circ} \mathrm{C}$ until used. The quality and concentration of RNA was assessed by Nanodrop (Thermo Scientific, USA). Reverse transcription was carried out using Revert aid kit (Fermentas, USA) as per manufacturer's instructions. Briefly, cDNA was synthesized in a total of $20 \mu \mathrm{l}$ reaction volume, using $2 \mu \mathrm{g}$ of RNA isolated from cAF-MSCs. Reaction was reverse-transcribed using Molony-Murine Leukemia Virus Reverse Transcriptase (MMLV-RT) (Fermentas, MD, USA) by incubating at $700 \mathrm{C}$ for $5 \mathrm{~min}$ followed by incubation at $25^{\circ} \mathrm{C}$ for $5 \mathrm{~min}, 42^{\circ} \mathrm{C}$ for $60 \mathrm{~min}$ and finally reaction was stopped by incubating for $10 \mathrm{~min}$ at $70^{\circ} \mathrm{C}$. The quality of cDNA was assessed by an amplification reaction for a housekeeping gene $\beta$-actin. RT-PCR analysis of surface markers was done for CD90, CD 73 and CD 105 using primers details of which given in Table 1.

\section{Relative expression level of pluripotency markers (Oct4, Sox2 and Nanog)}

Oct4, Sox 2 and Nanog were analyzed using SYBR Green based real time assay with $2 \mu \mathrm{g}$ of initial template in each qPCR reaction (MX3000P; Stratagene, CA, USA). Each reaction was prepared using Maxima ${ }^{\text {ma }}$ SYBR Green/ROX qPCR master mix (2X) (Fermentas, MD, USA). The qPCR reaction was optimized prior to actual experimentation with regard to primer concentrations, reaction efficiency and denaturation/ extension temperature for each pair of primers. The optimized reaction was carried out in duplicates at a final reaction volume of 25 $\mu \mathrm{l}$ containing $1 \mu \mathrm{l}(0.5 \mu \mathrm{mol} / \mathrm{L}$ concentrations $)$ of each forward and reverse primer, $3 \mu \mathrm{l}$ of cDNA, $7.5 \mu \mathrm{l}$ of nuclease free water and $12.5 \mu \mathrm{l}$ SYBR Green qPCR master mix (2X). No-reverse transcription control (No-RT) and No-template controls (NTC) were also included in each qPCR reaction, whereas $\beta$-actin was used as the endogenous control. The qPCR cycling was performed as follows; initial denaturation at $95^{\circ} \mathrm{C}$ for $10 \mathrm{~min}$ followed by 40 cycles of denaturation at $95^{\circ} \mathrm{C}$ for 25 $\mathrm{s}$, annealing at $55-60^{\circ} \mathrm{C}$ for $20 \mathrm{~s}$ varied with respect to primers used as given in Table 2 and extension at $72^{\circ} \mathrm{C}$ for $25 \mathrm{~s}$ and finally a melting curve profile was set at $95^{\circ} \mathrm{C}(1 \mathrm{~min}), 60^{\circ} \mathrm{C}(1 \mathrm{~min}), 95^{\circ} \mathrm{C}(30 \mathrm{~s})$. The final dissociation stage was performed for fluorescent acquisition and reaction specificity. The cycle threshold $(\mathrm{Ct})$ values given by the MxPro software (Agilent Technologies, USA) were used for further analysis. Relative expression level of pluripotency markers were analyzed using $2-\Delta \Delta \mathrm{Ct}$ method and the results were depicted graphically [12].

\section{Immunocytochemistry}

Third passage bWJ-MSCs cultured in 24-well plates up to $80 \%$ confluency were fixed using $4 \%$ paraformaldeyde, permeabilized

\begin{tabular}{|c|c|c|c|}
\hline Target genes & Primer sequences, 5'-3' & Gene bank accession no & Annealing temperature \\
\hline CD 73 & $\begin{array}{l}\text { S: CTGAGACACCCGGATGAGAT } \\
\text { A: ACTGGACCAGGTCAAAGGTG }\end{array}$ & BT_02624 & 55 \\
\hline CD 90 & $\begin{array}{l}\text { S: GTGAACCAGAGCCTTCGTCT } \\
\text { A: GGTGGTGAAGTTGGACAGGT }\end{array}$ & NM_001034765.1 & 55 \\
\hline CD 105 & $\begin{array}{l}\text { S: ACAAAGGCCTCGTCCTACCT } \\
\text { A: TGTGGTTGGTGCTACTGCTC }\end{array}$ & NM_001076397.1 & 59 \\
\hline$\beta$ actin & STEM TAG PCR primer set Cell bio labs inc & & 5 \\
\hline
\end{tabular}

Table 1: Oligonucleotide primers used for RT-PCR. 
Citation: Sreekumar TR, Ansari MM, Chandra V, G Sharma T (2014) Isolation and Characterization of Buffalo Wharton's Jelly Derived Mesenchymal Stem Cells. J Stem Cell Res Ther 4: 207. doi:10.4172/2157-7633.1000207

Page 3 of 6

\begin{tabular}{|c|c|c|c|c|}
\hline Target genes & Primer sequences, $5^{\prime}-3^{\prime}$ & Gene bank accession no & Annealing temperature & Product size $(\mathrm{kb})$ \\
\hline Oct4 & $\begin{array}{l}\text { S: GAGCCGAACCCTGAGGAG } \\
\text { A: AGGGTAAGCCCCACATCG }\end{array}$ & JF898834.1 & 60 & 125 \\
\hline Sox & $\begin{array}{l}\text { S: CTATGACCAGCTCGCAGAC } \\
\text { A: ACTTCACCACCGAGCCCA }\end{array}$ & GQ451841.1 & 60 & 111 \\
\hline Nanog & $\begin{array}{l}\text { S: GCAGGTGAA GACCTG GTTC } \\
\text { A: CCACATGGGCAGGTT TCCA }\end{array}$ & JF 898835.1 & 60 & 175 \\
\hline$\beta$ actin & $\begin{array}{l}\text { S: AGA TTG GCA TGG CTT TAT TTG T } \\
\text { A: CTG TAG AAC TTT GGG AAT GCT C }\end{array}$ & ВТ030480 & 51 & 143 \\
\hline
\end{tabular}

Table 2: Primers used for Real time PCR.

with $0.1 \%$ Triton-X-100 (only for transcriptional factor localization) and incubated with $0.01 \mathrm{M}$ sodium citrate solution for $10 \mathrm{~min}$ at room temperature to expose the antigens. Permeabilized cells were washed in DPBS, followed by blocking the background staining by incubating with normal donkey serum (Santa Cruz, USA; \#sc-2044) equilibrated in $0.5 \mathrm{M}$ DPBS ( $\mathrm{pH} 7.4$ ) for $30 \mathrm{~min}$. The cells were overlaid with primary antibodies at a dilution rate of 1:200 and incubated for $1 \mathrm{~h}$ at $37^{\circ} \mathrm{C}$. After brief washing with DPBS, the cell monolayer was incubated with Fluorescein isothiocyanate (FITC) conjugated donkey anti-goat secondary antibody at 1:400 dilution rate for $45 \mathrm{~min}$ at $37^{\circ} \mathrm{C}$ in dark. Thereafter, the cells were washed with DPBS and observed under the fluorescence microscope. Negative controls were exempted from exposure to primary antibody. Primary antibodies used in this experiment were against CD-73 (\#sc-32299), CD-90 (\#sc-59396), CD105 (\#sc-18838), CD-34 (\#sc-7324), Oct-4 (\#sc-8628), Nanog (\#sc30328), Sox-2 (\#sc-17320).

\section{Statistical analysis}

Real time PCR data was analyzed by one way ANOVA using graph pad prism (La Jolla, CA, USA) at $0.05 \%$ level of significance. Differences with $\mathrm{p}<0.005$ were considered as statistically significant.

\section{Results}

\section{Growth and culture characteristics of cWJ-MSCs}

Morphologically cells appeared as migrating from jelly explants during primary culture incubation (Figures $1 \mathrm{~A}$ and $1 \mathrm{~B}$ ) Later its morphology changed to typical fibroblast like spindle shaped cells (Figure 1C). After 7 days of incubation plastic adherent primary culture of monolayer cells with $80 \%$ confluent monolayer was
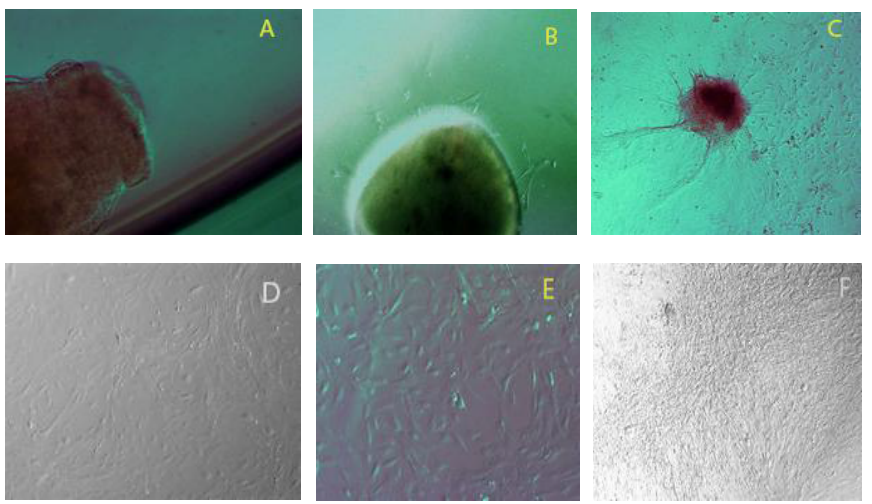

Figure 1: Morphological features of bWJ-MSC culture. Primary culture of bWJMSCs (A) On the day of seeding of jelly explant. (B) On day 3 attached jelly explant. (C) On day 5 fibroblastoid shaped cells extruding from jelly explant. (D) \& (E) On day 7 typical fibroblast like spindle shaped cell morphology. (F) Confluent cells after first passage. obtained (Figure 1D and 1E). Passaging of cells was done with accutase treatment and further re-seeding and culture was done (Figure $1 \mathrm{~F}$ ). Cell monolayer formed by buffalo Wharton's jelly derived MSCs after 3rd passage showed alkaline phosphatase activity on day four of culture, as it appeared red when visualized under inverted microscope demonstrating the undifferentiated nature of these cells (Figures $2 \mathrm{~A}$ and $2 \mathrm{~B})$.

\section{Differentiation potential of bWJ-MSCs}

In osteogenic cultures, cells proliferated and reached to complete confluency after 6-8 days of incubation. The cellular aggregates were then observed in osteogenic differentiation culture plates by $7-8$ th day of co-incubation and gradually increased till the end of the experiment. These aggregates were characterized by calcium deposits, which were demonstrated brownish black through von Kossa staining (Figure 3C). Small lipid droplets within the cytoplasm of bWJ-MSCs started appearing by 12th day of co-culture with specific induction media. Reddish colored lipid droplets could be demonstrated by Oil Red $\mathrm{O}$ staining on 21 st day of culture (Figure 3B). The chondrogenic potential of bWJ-MSCs was evaluated by in vitro culture of these cells in a serumfree chondrogenic specific medium. After 3 weeks of differentiation, the accumulation of sulfated proteoglycans was visualized by alcian blue staining (Figure 3A).
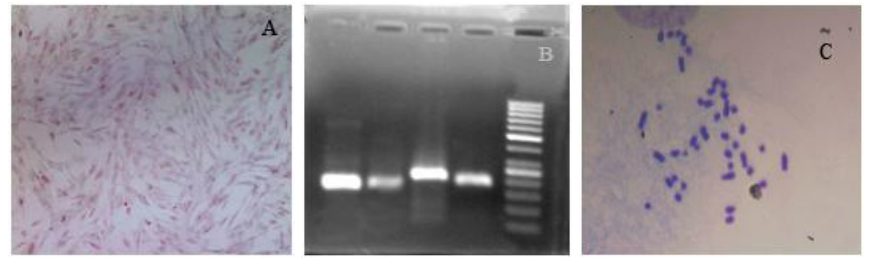

Figure 2: (A) Alkaline phosphatase staining showing red coloured AP positive cells. (B) RT-PCR expression profile of markers CD 73, CD 90 and CD 105. Lane1- Bactin, Lane 2- CD-73,Lane 3- CD90, Lane 4- CD105, Lane 5- 50bp ladder. (C) Karyotype of BWJ-MSC.
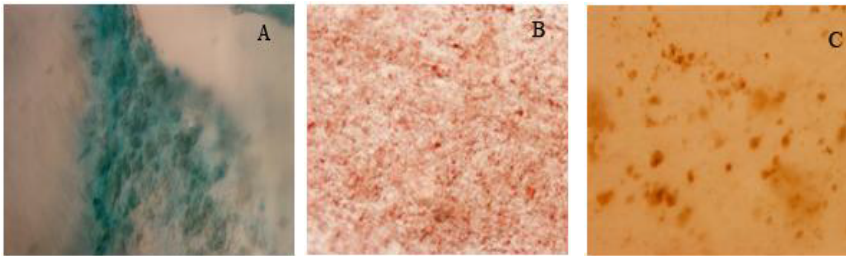

Figure 3: Invitro multilineage differentiation of bWJ-MSCs.(A) Positive staining of Alcian blue indicated invitro expanded bWJ-MSCs could differentiate into chondrocytes.(B) Specific Oil red $\mathrm{O}$ staining indicated adipogenesis induced lipid droplets observed in red colour on incubation with specific adipogenic induction media. (C) Brownish black coloured mineral deposition as demonstrated by Von kossa staining showing osteogenic differentiation. 

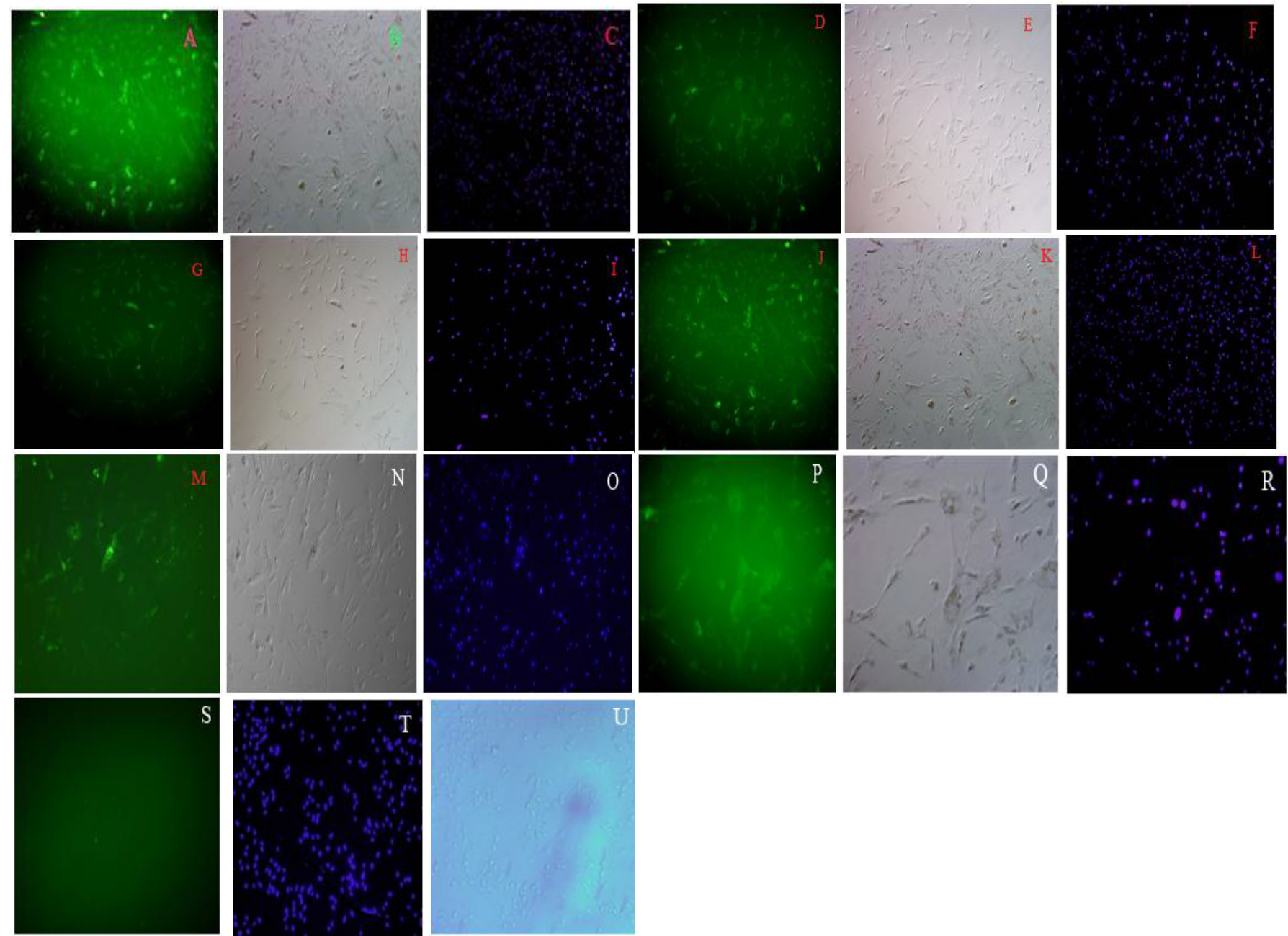

Figure 4: Immunocytochemistry. Immunolocalization of both surface antigens and pluripotency associated markers in bWJ-MSCs monolayer. Cells were stained with primary antibodies directed against (A) CD73, (D) CD90, (G) CD105, (J) Oct4, (M) Sox2, and (P) Nanog, (S) CD34 amd stained with FITC conjugated secondary antibodies. In panels $(\mathrm{B}, \mathrm{E}, \mathrm{H}, \mathrm{K}, \mathrm{N}, \mathrm{Q}, \mathrm{U})$ representative fields as observed under bright field. In panels (C, F.I, L, O, R, T) flurescent blue coloured DAPI stained representative fields.

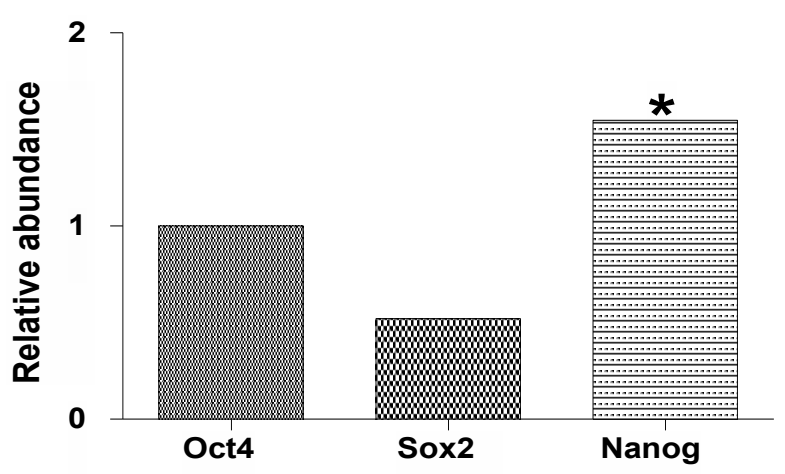

Figure 5: Real time PCR analysis of pluripotency markers in expanded bWJMSCs. Bar diagram showing higher relative abundance ( mean $\pm S E ; n=2$ ) of Nanog transcripts in comparison to Oct4 and Sox2.Asterix $\left(^{*}\right)$ indicates significant difference $(\mathrm{P}<0.005)$.

\section{Karyotyping}

Karyotype of bWJ-MSCs showed intact chromosomes. Metaphase spreads of buffalo WJ- MSCs showed normal karyotype at different passage and there were no abnormalities like chromosomal fragmentation (Figure 2C).

\section{Surface antigen profile of bWJ-MSCs}

A group of positive surface markers for MSCs viz. CD73, CD90, CD105 and Stro1 were tested by RT-PCR and immunocytochemistry. bWJ-MSCs were found positive for CD-73, CD-105 and CD-90 (Figure 4A-4I) but negative for haematopoietic cell surface marker CD-34 (Figure $4 \mathrm{~S}-4 \mathrm{U})$.

\section{Expression of pluripotency associated markers in bWJ-MSCs}

Pluripotency associated transcriptional factors (Oct-4, Nanog, Sox-2) were successfully localized in the bWJ-MSCs cell monolayer via immunocytochemistry (Figure 4J-4R) and Real time PCR (Figure 5) 
The transcript copy number of Nanog was found relatively higher than that of Oct4 and Sox 2 .

\section{Discussion}

Considering the invasive techniques involved in isolation of MSCs there is an increasing interest in investigating the potential of MSCs in adult and extra-embryonic sources, such as fetal membranes, amniotic fluid and umbilical cord matrix [13-15]. Also the collection of extraembryonic adnexa is safe and easy, are viable, accessible and not risky source of MSCs. High initial sample volumes Wharton's jelly could easily be collected at the delivery without any invasiveness for the buffalo.

The Wharton's Jelly, connective tissue of the umbilical cord has recently drawn an attention of researchers to focus as a new potential source of MSCs both in humans and farm animals [16-20].

In the case of buffalo, Wharton's jelly derived MSCs isolated by explant culture method, homogenous fibroblastoid cells colonies could be established successfully. Similar reports exist from Babei et al. [7] and later by Azari et al. [21], Pratheesh et al. [22] for caprine species.

The property of plastic adherence itself is not sufficient to allow for the purification of MSCs. Much valuable information can also be gained from a systematic analysis of cell surface molecules on MSCs. For characterization, we carried out alkaline phosphatase staining and immunophenotyping assays, as adapted by Hoynowski et al. [23]. AP positive staining demonstrated their high phosphatase activity - a unique feature of undifferentiated stem cells. STRO-1 was identified as an antibody that reacted with non-haematopoietic progenitor bone marrow stromal cells [24]. Endoglin (CD105) [25] antibody has been used in immunomagnetic selection methods for human MSCs, although CD105 is dominantly associated with endothelial cells [26]. Wharton's jelly derived stem cells exhibited specific mesenchymal stem cell marker expression (CD73, STRO-1, CD90 and CD105) based on RT-PCR and immunocytochemistry results.

The general strategy for identifying in vitro cultivated mesenchymal stem cells as per ISCT (International Society for Cytotherapy) is to analyze the expressions of cell-surface markers such as CD-73, CD90 and CD-105 and lack expression of CD34 or CD19 [1,27-29]. We demonstrated that the bWJ-MSCs are positive for CD-73, CD-90, and CD-105 whereas, negative for CD-34, a cell-surface marker associated with lympho-hematopoietic cells. They were also found positive for pluripotency markers like Oct4, Sox 2 and Nanog. The real time data demonstrated higher levels of Nanog marker expression in comparison to other pluripotency markers.

Present study demonstrated that they successfully differentiated into adipogenic, osteogenic and adipogenic lineages. This is at par with similar reports from human, equine, and bovine umbilical cord tissue and explanted as primary culture $[4,23,30]$.

\section{Conclusion}

Present study showed that buffalo mesenchymal stem cells could be successfully isolated and cultured and characterized from buffalo Wharton's jelly. Their morphology, immunophenotype and differentiation potential are comparable with MSCs from other source. Expression of pluripotency markers demonstrates their potency. Data from the present study demonstrates the proliferative and differentiation potential of bWJ-MSCs and Buffalo Wharton's jelly could serve as a potent source of mesenchymal stem cells. With future research and standardization they could serve as valuable resource for various clinical applications.

\section{References}

1. Dominici M, Le Blanc K, Mueller I, Slaper-Cortenbach I, Marini F, et al. (2006) Minimal criteria for defining multipotentmesenchymal stromal cells. The International Society for Cellular Therapy position statement. Cytotherapy 8: 315-317.[PubMed]

2. Mitchell KE, Weiss ML, Mitchell BM, Martin P, Davis D, et al. (2003) Matrix cells from Wharton's jelly form neurons and glia. Stem Cells 21: 50-60.[PubMed]

3. Kobayashi K, Kubota T, Aso T (1998) Study on myofibroblast differentiation in the stromal cells of Wharton's jelly: expression and localization of alphasmooth muscle actin. Early Hum Dev 51: 223-233.[PubMed]

4. Wang HS, Hung SC, Peng ST, Huang CC, Wei HM, et al. (2004) Mesenchymal stem cells in the Wharton's jelly of the human umbilical cord. Stem Cells 22 1330-1337.[PubMed]

5. Troyer DL, Weiss ML (2008) Wharton's jelly-drived cells are a primitive stromal cell population. Stem Cells 26: 591-599.[PubMed]

6. Yang CC, Shih YH, Ko MH, Hsu SY, Cheng H, et al. (2008) Transplantation of human umbilical mesenchymal stem cells from Whartons jelly after complete transection of the rat spinal cord. PLoS ONE 3: 1-11.[PubMed]

7. Babaei H, Moshrefi M, Golchin M, Nematollahi-Mahani SN (2008) Assess the pluripotency of caprine umbilical cord Wharton's jelly mesenchymal cells by RT-PCR analysis of early transcription factor nanog. Iran J Vet Surg 3: 57-65.

8. Sharma M, Kumar R, Dubey PK, Verma OP, Nath A, et al. (2012) Expression and quantification of Oct-4 gene in blastocyst and embryonic stem cells derived from in vitro produced buffalo embryos. In Vitro Cell Dev Biol - Anim 48: 229 235.[PubMed]

9. Sheehan D, Hrapchak B (1980) Theory and Practice of Histotechnology, second ed. Battelle Press, Ohio 226-22.

10. Baghaban Eslaminejad M, Nazarian H, Taghiyar L (2008) Mesenchymal stem cell isolation from the removed medium of rat's bone marrow primary culture and their differentiation into skeletal cell lineages. Yakhteh Medical Journal 10 65-72

11. Nekanti U, Mohanty L, Venugopal P, Balasubramanian S, Totey S, et al. (2010) Optimization and scale-up of Wharton's jelly-derived mesenchymal stem cells for clinical applications. Stem Cell Research 5: 244-254.[PubMed]

12. Pfaffl MW (2001) A new mathematical model for relative quantification in realtime RT-PCR. Nucleic Acids Research 29: 2002-2007.[PubMed]

13. Marcus AJ, Woodbury D (2008) Fetal stem cells from extra-embryonic tissues: do not discard. J Cell Mol Med 12: 730-742.[PubMed]

14. Parolini O, Alviano F, Bagnara GP, Bilic G, Bühring HJ, et al. (2008) Concise review: isolation and characterization of cells from human term placenta: outcome of the first international Workshop on Placenta Derived Stem Cells. Stem Cell 26: 300-311.[PubMed]

15. Secco M, Zucconi E, Vieira NM, Fogaça LL, Cerqueira A, et al. (2008) Multipotent stem cells from umbilical cord: cord is richer than blood. Stem Cells 26: 146-150.[PubMed]

16. Mueller SM, Glowacki J (2001) Age-related decline in the osteogenic potential of human bone marrow cells cultured in three-dimensional collagensponges. $J$ Cell Biochem 82: 583-590.[PubMed]

17. Cremonesi F, Violini S, Lange Consiglio A, Ramelli P, Ranzenigo G, et al (2008) Isolation in vitro culture and characterization of foal umbilical cord cells at birth. Vet Res Commun 32: 139-142.[PubMed]

18. Barholomew S, Owens SD, Ferraro GL, Carrade DD (2009) Collection of equine cord blood and placental tissues in 40 thoroughbred mares. Equine Vet J 41: 724-728.[PubMed]

19. Passeri S, Nocchi F, Lamanna R, Lapi S (2009) Isolation and expansion of equine umbilical cordderived matrix cells (EUCMCs). Cell Biol Int 33: 100-105. [PubMed]

20. Pratheesh MD, Gade NE, Katiyar AN, Dubey PK, Sharma B, et al. (2013) Isolation, culture and characterization of caprine mesenchymal stem cells derived from amniotic fluid. Res Vet Sci 94: 313-319.[PubMed]

21. Azari O, Babaei H, Derakhshanfar A, Nematollahi-Mahani SN, Poursaheb 
Citation: Sreekumar TR, Ansari MM, Chandra V, G Sharma T (2014) Isolation and Characterization of Buffalo Wharton's Jelly Derived Mesenchymal Stem Cells. J Stem Cell Res Ther 4: 207. doi:10.4172/2157-7633.1000207

$\mathrm{R}$, et al. (2011) Effects of transplanted mesenchymal stem cells isolated from Wharton's jelly of caprine umbilical cord on cutaneous wound healing; histopathological evaluation. Vet Res Commun 35: 211-222.[PubMed]

22. Pratheesh MD, Gade NE, Dubey PK, Nath A, Sivanarayanan TB, et al. (2014) Molecular characterization and xenogenic application of Wharton's jelly derived caprine mesenchymal stem cells. Vet Res Commun [Epub ahead of print].

23. Hoynowski SM, Fry MM, Gardner BM, Leming MT, Tucker JR, et al. (2007) Characterization and differentiation of equine umbilical cord-derived matrix cells. Biochem Biophys Res Commun 362: 347-353.[PubMed]

24. Simmons PJ, Torok-Storb B (1991) Identification of stromal cell precursors in humanbone marrow by a novel monoclonal antibody, STRO-1. Blood 78: 5562.[PubMed]

25. Barry FP, Boynton RE, Haynesworth S, Murphy JM, Zaia J (1999) The monoclonal antibody $\mathrm{SH}-2$, raised against human mesenchymal stem cells, recognizes an epitope on endoglin (CD105). Biochem Biophys Res Commun 265(1): 134-139.[PubMed]

26. Cheifetz S, Bellon T, Cales C, Vera S, Bernabeu C, et al. (1992) Endoglin is a component of the transforming growth factor-beta receptorsystem in human endothelial cells. J Biol Chem 267: 19027-19030.[PubMed]

27. Donzelli E, Salvade A, Mimo P, Vigano M, Morrone M, et al. (2007) Mesenchyma stem cells cultured on a collagen scaffold:In vitro osteogenic differentiation. Archives of Oral Biology 52: 64-73.[PubMed]

28. Yu Y, Yao AH, Chen N, Pu LY, Fan Y, et al. (2007) Mesenchymal stem cells over-expressing hepatocyte growth factor improve small-for-size liver grafts regeneration. Molecular Therapy 15: 1382-1389.[PubMed]

29. De Macedo Braga LM, Lacchini S, Schaan BD, Rodrigues B, Rosa K, et al (2008) In situ delivery of bone marrow cells and mesenchymal stem cells improves cardiovascular function in hypertensive rats submitted to myocardial infarction. Journal of Biomedical Science 15: 365-374.[PubMed]

30. Raoufi MF, Tajik P, Dehghan MM, Eini F, Barin A (2011) Isolation and differentiation of mesenchymal stem cells from bovine umbilical cord blood. Reprod Domest Anim 46: 95-99.[PubMed] 